\title{
PSIKOLOGI ISLAM PERSPEKTIF MALIK BADRI
}

\author{
Zaharuddin \\ Fakultas Psikologi UIN Raden Fatah Palembang \\ zaharuddin_uin@radenfatah.ac.id
}

\begin{abstract}
This study aims to reveal the concept of Islamic psychology Malik Badri perspective. The concept of Islamic psychology that is expressed in the form of approach in formulating the theory of Islamic psychology, the process of development stage of Islamic psychology and the nature of Islamic psychology. This study is a kind of literature research, by doing a review of the works of Malik Badri. In analyzing this literature study, researchers used content analysis. The conclusion in this first study, that approach in the development of Islamic psychology using a combination of approaches between scriptures, philosophical and tasawwufi (sufistik) and using pragmatic methods and idealistic methods. Second, the stage of Islamic psychology development begins with the stage of awe, acceptance and emancipation. Third, the essence of Islamic psychology according to Malik Badri is an effort in formulating the concept of psychological theory based on the study of the Qur'an and hadith which aims to filter out theoretical concepts contrary to Islamic ideology
\end{abstract}

Keywords: : Malik Badri Perspective, Islamic Psychology

\begin{abstract}
ABSTRAK
Pengkajian ini bertujuan untuk mengungkap konsep psikologi Islam perspektif Malik Badri. Konsep psikologi Islam yang diungkap berupa pendekatan dalam merumuskan teori psikologi Islam, proses tahapan pengembangan psikologi Islam dan hakikat psikologi Islam. Kajian ini merupakan jenis penelitian pustaka, dengan cara melakukan telaah terhadap karya-karya dari Malik Badri. Dalam menganalisis kajian pustaka ini, peneliti menggunakan analisis isi (content analysis). Kesimpulan dalam kajian ini pertama, bahwa pendekatan dalam pengembangan psikologi Islam menggunakan kombinasi pendekatan antara skriptualis, filosofis dan tasawwufi (sufistik) dan menggunakan metode pragmatis dan metode idealistik. Kedua, tahapan pengembangan psikologi Islam dimulai dengan dimana tahapan terpersona, penerimaan dan emansipasi. Ketiga, hakikat psikologi Islam menurut Malik Badri adalah upaya dalam merumuskan konsep teori psikologi berdasarkan kajian terhadap al-Qur'an dan hadis yang bertujuan untuk memfilter konsep teori yang bertentangan dengan ideologi Islam.
\end{abstract}

Kata Kunci: Perspektif Malik Badri, Psikologi Islam

\section{PENDAHULUAN}

Perkembangan ilmu psikologi dalam perspektif psikologi Islam, hingga periode ini semakin menunjukkan kemajuan yang pesat. Menurut Brennan, sejarah perkembangan teori dan model psikologi berkembang perlahan, sebagian besar berkembang dalam filsafat, hingga abad ke-19, ketika semangat metodologis ilmu pengetahuan, diterapkan ke dalam studi psikologi yang muncul sebagai produk institusi intelektual Barat (James Brenna, 2006).
Begitupun perkembangan psikologi Islam itu sendiri mengalami pelbagai kemajuan walaupun kesannya perlahan. Setelah terjadinya Islamisasi ilmu pengetahuan yang dipelopori oleh Ismail Raji al-Faruqi dan Syed Muhammad Naquib alAttas, untuk menggali Alquran dan Sunnah sebagai sumber pengembangan ilmu pengetahuan (islamisasi ilmu (Siti Faridah, 2010).

Menurut Subandi (2005) ada dua alasan yang mendorong ilmuwan muslim melaksanakan islamisasi sains. Pertama, 
semakin terkotak-nya antara sains dan agama yang mengakibatkan ditinggalkannya nilainilai moral dan etika. Hal ini terlihat dari semakin majunya peradaban suatu negara karena kemajuan sains, ternyata membawa dampak berbagai kerawanan sosial dan psikologis. Kedua adalah keinginan ilmuwan muslim untuk melihat kembali kejayaan ilmuwan muslim seperti pada abad pertengahan setelah mentransfer berbagai bentuk pengetahun dari budaya Yunani dan Romawi. Meskipun tidak persis sama, tetapi situasi yang dihadapi oleh ilmuwaan di dunia muslim saat ini tampaknya mirip dengan situasi umat Islam di abad pertengahan itu. Ini bukanlah sekedar utopia ilmuwan muslim yang sedang dalam posisi underdog, tetapi secara obyektif hal ini juga diakui oleh ilmuwan Barat sendiri. Bahkan beberapa ilmuwan memprediksikan akan adanya perseteruan dan pertempuran kebudayaan (setelah perseteruan antara dua super-power dunia), yaitu pertentangan antara budaya Barat dan budaya Islam, yang salah satu di antaranya adalah di bidang ilmu pengetahuan.

Walaupun demikian, pada masa abad ke 20 ini, perkembangan psikologi Islam semakin pesat. Hal ini dapat tercermin salah satunya yaitu telah banyak para pemerhati psikologi yang mulai memperhatikan aspek agama dalam kajian lmu psikologi. khususnya di Indonesia, banyak pemerhati psikologi yang melakukan penelitian yang berhubungan dengan keterkaitan antara agama dengan agama. Kenapa dibutuhkan psikologi Islam, hal ini dikarenakan ketidakpuasan terhadap konsep psikologi konvensional yang sudah ada.

Terdapat empat aliran atau mazhab besar dalam ilmu psikologi yang telah diakui secara umum oleh komunitas akademisi di bidang psikologi, yaitu psikoanalisa, behaviourisme, humanias dan transpersonal. Jika melihat sejarah kelahirannya, maka dapat diambil suatu penjelasan bahwa, lahirnya satu mazhab ke mazhab lainnya, disebabkan oleh ketidakpuasan ataupun ketidak setujuan terhadap paradigma mazhab yang telah ada.

Seperti mazhab psikoanalisa yang disebut sebagai mazhab pertama dalam psikologi, dipelopori oleh Sigmund Freud. Mazhab psikoanalisa memandang aktivitas manusia merupakan proses-proses mental dan proses aktivitas sadar dan tidak sadar dalam diri manusia. Pandangan mazhab psikoanalisa, ditentang oleh mazhab kedua dalam psikologi yaitu mazhab behaviourisme, yang dipelopori oleh John Broadus Watson. Mazhab behaviourisme memandang bahwa aktivitas manusia bukan dipengaruhi oleh aktivitas kesadaran dalam diri, melainkan oleh adaptasi perilaku dan pembelajaran tersebut dikendalikan oleh prinsip-prinsip asosiasi. Lebih lanjut pandangan mazhab kedua ini ditentang oleh mazhab ketiga dalam psikologi yaitu mazhab humanistik, tokohnya seperti Allport, Buhler, Maslow, May dan Rogers. Dalam mazhab humanistik memandang bahwa individu berusaha mencapai perkembangan potensinya dan menolak penjelasan mekanis dan materialistik atas proses-proses psikologis.

Lebih lanjut setelah kelahiran mazhab ketiga yaitu mazhab humanistik. Lahir juga yang disebut sebagai mazhab ke empat yaitu mazhab transpersonal, salah satunya dipelopori oleh Abraham Maslow. Konsep utama mazhab transpersonal memandang manusia tidak hanya mempunyai kesadaran psiko-fisik, psiko-kognitif atau psikohumanistik, namun juga manusia mempunyai kesadaran yang terdalam dan tinggi sifatnya (Mujidin, 2005).

Berdasarkan sejarah dan konsep yang dibangun oleh masing-masing ke empat mazhab besar psikologi yaitu psikoanalisas, behaviourisme, humanistik dan transpersonal. Terlihat bahwa kelahiran dari satu mazhab ke mazhab dikarenakan adanya ketidakpuasan oleh pemerhati perkembangan ilmu psikologi 
terhadap paradigma mazhab psikologi yang dibangun untuk memahami manusia.

Permasalahan yang ada adalah, hingga saat ini perkembangan psikologi Islam masih dalam proses yang tidak mudah. Dalam asumsi peneliti, hal ini disebabkan oleh belum ada kesepakatan mengenai pendekatan dalam merumuskan teori psikologi Islam, metode yang digunakan dalam penelitian psikologi islam masih dianggap belum mumpuni, serta pahama yang berbeda tentang hakikat psikologi Islam itu sendiri, baik dari pengkaji dalam bidang agama maupun dalam bidang psikologi itu sendiri.

Dalam tulisan ini, peneliti tertarik untuk mengkaji pandangan salah satu tokoh pemerhati psikologi Islam, yang mungkin belum banyak dikenal oleh sebagian akademisi, baik dibidang psikologi konvensional, maupun psikologi Islam itu sendiri. Tokoh tersebut bernama Malik Badri.

Malik Badri adalah salah satu tokoh pelopor perkembangan psikologi Islam. Gerakan psikologi Islam secara objektif berawal ketika Malik B Badri, seorang psikolog dari sebuah negara di Afrika, menerbitkan buku The Dilemma of Moslem Psychologist pada tahun 1979. Buku yang mengkritik secara tajam psiokologi Barat ini telah mendapat sambutan luar biasa dan menjadi pemicu bagi munculnya pemikiran Psikologi Islami. Di Indonesia gerakan ini dimulai tahun 1990-an yang gaungnya semakin keras di awal milineum ketiga ini. Beberapa pertemuan nasional telah dilaksanakan dan buku-buku mulai banyak diterbitkan.

Dalam tulisan ini, peneliti mengkaji bagaimana pendekatan psikologi Islam perspektif Malik Badri. Diantara judul karya Malik Badri yang berhubungan dengan keterkaitan antara psikologi dengan Islam ada yang sudah diterjemahkan ke bahasa Indonesia. Dalam tulisan ini, peneliti mau mengkaji bagaimana sesungguhnya konsep psikologi Islam dalam perspektif Malik Badri.

\section{PERUMUSAN MASALAH}

Berdasarkan beberapa identifikasi masalah yang ada, peneliti merumuskan yang menjadi fokus rumusan masalah dalam penelitian ini adalah: Bagaimana pendekatan yang digunakan Malik Badri dalam merumuskan teori psikologi Islam ?

\section{METODE PENELITIAN}

Setiap penelitian memiliki metode tersendiri dalam penyelesaiannya, begitupun pada kajian ini. Kajian ini merupakan jenis penelitian pustaka. Menurut Wibirama (2015) kajian studi pustaka merupakan karya tulis ilmiah yang memuat pembahasan penelitian terdahulu dan referensi ilmiah.

Kajian ini memfokuskan untuk menemukan pendekatan psikologi Islam perspektif Malik Badri. Prosedur pelaksanaan penelitian ini, diawalai dengan mengumpulkan karya-karya dari Malik Badri mengenai konsep psikologi Islam. Selanjutnya dilakukan telaah terhadap karyakarya dari Malik Badri.

Dikarenakan keterbatasan peneliti sendiri dan ketersediaan referensi yang kurang memadai, sehingga karya Malik Badri yang dikaji dalam penelitian ini yaitu meliputi: 1) The Dilemma of Muslim Psychologists (Dalam versi Bahasa Indonesia berjudul: Dilema Psikolog Muslim); 2) AlTafakkur min al-Musyahadah ila al-Syuhud: Dirasah al-Nafsiyah al-Islamiyah (Dalam versi bahasa Indonesia berjudul: Tafakkur: Perspektif Psikologi Islam); 3) Beberapa artikel jurnal yang ditulis oleh Malik Badri (peneliti mencari artikel jurnal dengan cara bantuan search engine google); 4) Karyakarya sekunder lainnya yang membahas tentang pendapat Malik Badri.

Selanjutnya setelah mengkaji referensi mengenai konsep psikologi Islam, peneliti 
memberikan kesimpulan sesuai dengan perumusan masalah. Sumber kajian ini berasal dari karya-karya dari Malik Badri, hasil-hasil penelitian terdahulu, artikel dan buku-buku yang berkaitan dengan tema penelitian. Dalam menganalisis kajian telaah ini, peneliti menggunakan analisis isi. Menurut Arikunto (2010) analisis isi merupakan jenis penelitian yang menghasilkan suatu kesimpulan tentang gaya bahasa buku, kecenderungan isi buku, tata tulis, lay-out, ilustrasi, dan sebagainya.

\section{HASIL PENELITIAN}

\section{Pendekatan dan Metode Perumusan Teori psikologi Islam}

Dalam analisa pertama yang dilakukan peneliti adalah untuk mengetahui bagaimana pendekatan yang dipakai Malik Badri dalam merumuskan teori-teori psikologi Islam. Dalam hal ini, peneliti melakukan telaah terhadap karya Malik Badri yaitu: "AlTafakkur min al-Musyahadah ila al-Syuhud: Dirasah al-Nafsiyah al-Islamiyah (Dalam versi bahasa Indonesia berjudul: Tafakkur: Perspektif Psikologi Islam)”. Karya Malik Badri tentang tafakkur ini, peneliti anggap sebagai salah satu tema dalam perspektif psikologi tentang proses berpikir dalam konsep psikologi Islam.

Dalam melakukan analisa pendekatan perumusan teori psikologi Islam dari persepsi Malik Badri. Peneliti menggunakan alat analisa berupa jenis pendekatan psikologi Islam menurut pendapat Abdul Mujib dan Jusuf Mudzakir. Menurut Abdul Mujib dan Jusuf Mudzakir (2002) pendekatan yang digunakan dalam membangun psikologi Islam sebagaimana yang pernah dipraktekan oleh para psikolog maupun terdahulu, setidaktidaknya meliputi tiga aspek yaitu pendekatan skriptualis, pendekatan filosofis dan pendekatan tasawwufi (sufistik). Ketiga pendekatan dalam psikologi Islam ini, berdasarkan tiga acuan yaitu wahyu, akal dan intuisi. Ketiga acuan tersebut digunakan secara simultan, walaupun salah satu di antaranya ada yang lebih dominan. Pendekatan skriptualis lebih mengutamakan wahyu, pendekatan filosofis mengutamakan akal dan pendekatan sufistik atau tasawwufi mengutamakan intuisi.

Pendekatan skriptualis adalah pendekatan pengkajian psikologi Islam yang didasarkan atas teks-teks Al-Qur'an ataupun hadis secara literal. Lafal-lafal yang terkandung di dalam Al-Qur'an maupun hadis petunjuknya sudah dianggap jelas dan tidak diperlukan lagi penjelasan di luar ayat atau hadis. Asumsi filosofinya adalah bahwa Allah Swt menciptakan jiwa manusia, dan Dia pula yang menciptakan hukum-hukum psikologisnya. Hukum-hukum psikologis dari Allah, tidak sedikitpun terlupakan dalam firman-Nya, sehingga penggalian hukumhukum itu cukup dengan mempelajari firmanNya.

Selanjutnya pendekatan falsafi adalah pendekatan pengkajian psikologi Islam yang didasarkan atas prosedur berpikir spekulatif. Prosedur yang dimaksud mencakup berpikir yang sistemik, radikal dan universal, yang ditopang oleh kekuatan akal sehat. Pendekatan falsafi ini tidak berarti meninggalkan nash, melainkan tetap berpegang teguh kepada nash, hanya saja cara memahaminya dengan mengambil makna esensial yang terkandung di dadalamnya. Akal yang sehat sesungguhnya datang dari Allah Swt, demikian juga nash berasal dariNya. Maka antara akal dan nash tidak akan terjadi pertentangan. Jika terjadi perbedaan antara nash dan akal, boleh jadi disebabkan oleh akal belum mampu menangkap pesan esensial nash, atau diperlukan interpretasi filosofis terhadap lafal dalam nash.

Pendekatan tasawwufi atau sufistik, yaitu pendekatan pengkajian psikologi Islam yang didasarkan pada prosedur intuitif, ilham dan cita rasa. Prosedur yang dimaksud 
dilakukan dengan cara menajamkan struktur kalbu melalui proses penyucian diri. Cara itu dapat membuka tabir yang menjadi penghalang antara ilmu-ilmu Allah dengan jiwa manusia, sehingga mereka memperoleh ketersingkapan dan mampu mengungkap hakikat yang sesungguhnya.

Berdasarkan analisa peneliti terhadap karya Malik Badri yaitu: "Al-Tafakkur min al-Musyahadah ila al-Syuhud: Dirasah alNafsiyah al-Islamiyah (Dalam versi bahasa Indonesia berjudul: Tafakkur: Perspektif Psikologi Islam)". Peneliti menemukan beberapa tema yang berkaitan dengan pendekatan-pendekatan dalam psikologi Islam yaitu pendektan skriptualis, pendekatan filosofis dan pendekatan tasawwufi.

Seperti ungkapan dari Malik Badri yaitu "dalam buku ini, saya memaparkan penemuan-penemuan penting dalam bidang psikologi modern yang membuktikan nilai dan pentingnya pikiran dan meditasi dalam membentuk dasar-dasar kognitif dan emosional, mengarahkan perilaku dan keinginan, menciptakan kebiasaan, mengobati kegoncangan, serta memantapkan kehidupan kejiwaan dan spiritualitas manusia”.

Dalam analisa peneliti jika menggunakan pendekatan dari pendapat Abdul Mujib dan Jusuf Mudzakir. Malik Badri dalam merumuskan pendekatan teori psikologi Islam, menggunakan pendekatan filosofis. Hal ini tampak dalam pernyataann dalam karyanya "dalam buku ini, saya memaparkan penemuan-penemuan penting dalam bidang psikologi modern.... malik Badri menggunakan pendekatan filosofis untuk mengungkapkaan teori dalam karyanya. Hal ini dapat peneliti asumsikan bahwa pendekatan filosofis yang dimaksud adalah mencakup berpikir yang sistemik, radikal dan universal. Hal ini disebabkan karena Malik Badri juga menggunakan pendapat-pendapat dari pemikir Modern psikologi konvensionaal dalam merumuskan teori psikologi Islam.
Selain pendekatan modern psikologi konvensional. Malik Badri juga merujuk pada pendapat pemikir muslim klasik. Sebagaimana Malik Badri juga mengungkapkan kajian tafakur dalam konsep pemikir muslim, seperti ungkapan Malik Badri Dalam kajian ini pun, saya membahas tabiat dan fase-fase tafakur menurut sebagian ulama klasik, seperti Al-Ghazali dan Ibnu Qayyim, kemudian membandingkan dengan penemuan psikologi kontemporer. Pendekatan falsafi yang digunakan Malik Badri tidak berarti meninggalkan nash, melainkan tetap berpegang teguh kepada nash, hanya saja cara memahaminya dengan mengambil makna esensial yang terkandung di dalamnya. Akal yang sehat sesungguhnya datang dari Allah Swt, demikian juga nash berasal dari-Nya. Maka antara akal dan nash tidak akan terjadi pertentangan. Jika terjadi perbedaan antara nash dan akal, boleh jadi disebabkan oleh akal belum mampu menangkap pesan esensial nash, atau diperlukan interpretasi filosofis terhadap lafal dalam nash ini.

Oleh karena itu, selain menggunakan pendapat modern psikologi konvensional melalui pendekatan falsafi, Malik Badri juga menggunakan pendekatan skriptualis. Hal ini ditunjukkan dalam pendapatnya yang menyatakan "Tentang kebiasaan tafakur tanpa melihat benda yang menjadi objeknya, Al-Qur'an juga menyerukan manusia untuk melihat segala ciptaan Allah swt. di alam raya ini yang tidak dapat dijangkau oleh kekuatan tangan manusia, seperti langit, gunung-gunung, dan lautan lepas. Al-Qur'an juga mengajak orang-orang mukmin untuk merenungkan nikmat Allah swt. berupa karya cipta yang dihasilkan oleh para ilmuan. Karena Allah swt. telah memberikan ilmu kepada mereka untuk kepentingan hidup dan kehidupan umat manusia. Terdapat dalam alQur'an Surat Al-Baqarah ayat 164: 


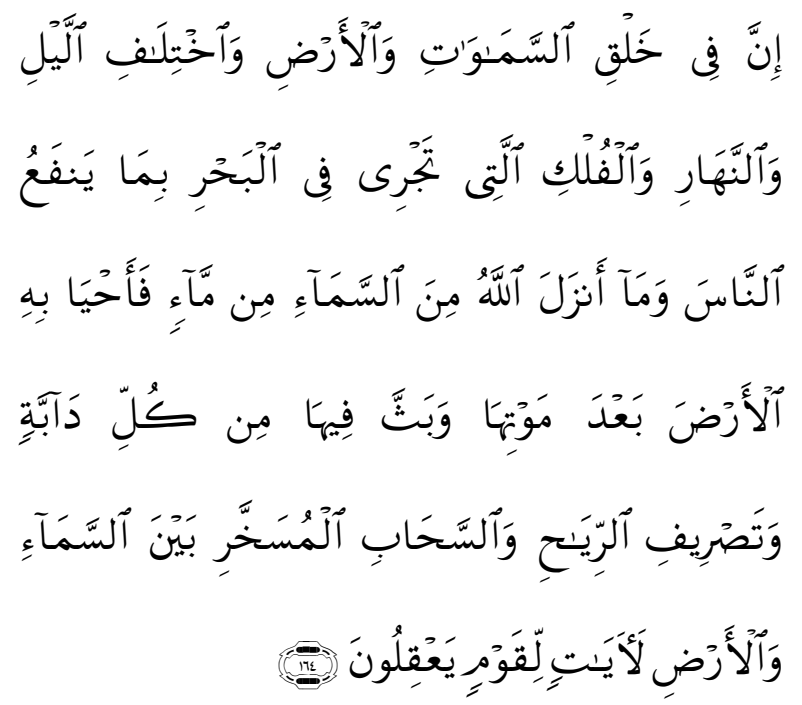

Artinya:

Sesungguhnya dalam penciptaan langit dan bumi, silih bergantinya malam dan siang, bahtera yang berlayar di laut membawa apa yang berguna bagi manusia, dan apa yang Allah turunkan dari langit berupa air, lalu dengan air itu Dia hidupkan bumi sesudah mati (kering)-nya dan Dia sebarkan di bumi itu segala jenis hewan, dan pengisaran angin dan awan yang dikendalikan antara langit dan bumi; sungguh (terdapat) tanda-tanda (keesaan dan kebesaran Allah) bagi kaum yang memikirkan.

Lebih lanjut pendapat Malik Badri "Tafakur merupakan bagaian ibadah yang bebas, artinya terlepas dari segala ikatan kecuali satu ikatan saja, yaitu tafakur tentang Zat Allah swt. Dialah Allah yang "Tidak ada satupun yang serupa dengan Dia, dan Dialah yang Maha Mendengar dan Maha Melihat" Al-Qur'an Surat Asy-Syura ayat 11:

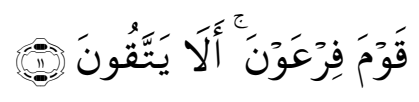

Artinya:

"(yaitu) kaum Fir'aun. mengapa mereka tidak bertakwa?"

Pendapat lanjutan Malik Badri lainnya mengenai bukti penggunaan pendektan skriptualis bahwa Malik Badri "memfokuskan kembali masalah yang telah kami singgung sebelumnya, bahwa pengetahuan manusia mengenai otak dan sarafnya sangat sedikit. Adapun hakikat akal, roh dan jiwanya merupakan rahasia yang terkunci rapat, merupakan harta simpanan yang menakutkan. Kalau pengetahuan manusia begitu terbatas dalam kehidupannya yang fana ini, bagaimana ia berani bertafakur tentang ZatNya yang "Dia tidak dapat dicapai oleh penglihatan mata, sedangkan Dia dapat melihat segala penglihatan itu, Al-Qur'an Surat Al-An'am: 103:

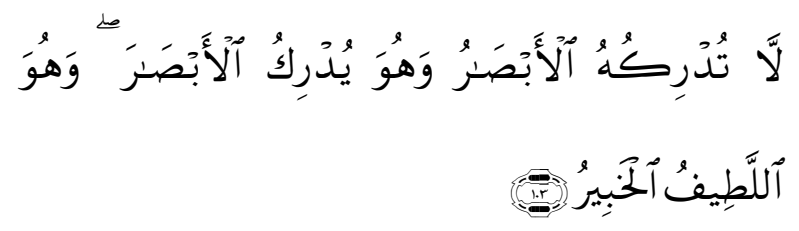

Artinya:

Dia tidak dapat dicapai oleh penglihatan mata, sedang Dia dapat melihat segala yang kelihatan; dan Dialah yang Maha Halus lagi Maha mengetahui.

Selanjutnya, selain Malik Badri menggunakan pendapat modern psikologi konvensional melalui pendekatan falsafi dan pendekatan skriptualis. Malik Badri juga menggunakan pendekatan tasawufi. Seperti pendapat Malik Badri, kajian hubungan antara tafakur tentang hukum-hukum alam dan metode ilmiah merupakan awal perhatian saya dalam upaya menghubungkan tafakur dengan kajian psikologi dan pendidikan modern. Kajian ini telah saya tulis secara ringkas sebelumnya dengan judul "Tafakur Tentang Alam dan Manusia: Antar Ibadah dan Ilmu" dalam Jurnal Majalat al-Kulliyat al- 'Ulum alIjitima'iyah, Universitas Islam Ibnu Sa'ud tahun $1401 \mathrm{H}$. Perhatian dan antusias para pembaca dan teman-teman dalam kajian tersebut mendorong saya untuk menulis buku ini. Semoga Allah swt. Memberi mereka pahala dan kebaikan. Menunjukkan bahwa 
ada pembahasan bukan hanya olah pikir, tetapi juga olah jiwa disini.

Lebih lanjut, bukti bahwasanya Malik Badri juga menggunakan pendekatan tasawuffi sebagaimana pndapat Badir yang menyatakan bahwa proses pengobatan atau terapi psikologi ini, juga dapat dilakukan dengan memberikan rangsangan atau stimulus yang bertolak belakang dengan pikiran dan perasaan emosional yang melahirkan kebiasaan. Oleh karena itu, terhadap pasien yang selalu takut hidup dengan masyarakat tertentu, psikolog terapi harus memberikan perasaan ketenangan, kenyamanan dan ketentraman jiwa kepadanya dengan cara membawanya ke keadaan sebenarnya dalam masyarakat yang ia takuti itu, atau dengan jalan membayangkan dalam khayalan.

\section{KESIMPULAN}

Dalam kajian penelitian ini, terdapat tuga kesimpulan bahwa pendekatan dalam pengembangan psikologi Islam dalam perspektif Malik Badri menggunakan kombinasi pendekatan antara skriptualis, filosofis dan tasawwufi (sufistik). Dalam artian bahwa Malik Badri menggunakan pendekatan perumusan teori psikologi Islam bersumber dari kajian terhadap alquran dan hadis (skriptualis), bersumber dari kajian spekulatif yang bersifat empiris dan hasil kajian pemikiran dan bersumber dari pemahaman dan penghayatan kasus-kasus atau tema-tema psikologi serta dalam prakteknya secara langsung. Selain itu metode yang digunakan adalah kombinasi antara metode pragmatis dan idealistik. Dalam artian bahwa Malik Badri melakukan adopsi teori barat dan juga mengkaji teori dari sumber utama Islam.

\section{DAFTAR PUSTAKA}

James F. Brennan, History and System of Psychology, diterjemahkan oleh Nurmala Sari Fajar, Sejarah dan
Sistem Psikologi, Jakarta, Rajawali Pers, 2006, hlm. 2

Siti Faridah, Perkembangan Psikologi Islam, Ilmu Ushuluddin, Juli 2010, hlm. 207-225, 208.

M.A. Subandi, Reposisi Psikologi Islam, Disampaikan pada Temu Ilmiah Nasional I Psikologi Islam, Yogyakarta, 24 September 2005, 2.

Mujidin, Garis Besar Psikologi Transpersonal: Pandangan Tentang Manusia dan Metode Penggalian Transpersonal Serta Aplikasinya Dalam Dunia Pendidikan, Jurnal Humanitas: Indonesia Psychological Journal, Vol, 2 No. 1 Januari (2005), hlm. 54

Iredho Fani Reza, Mengatasi Kerentanan Stres Melalui Coping Religius (Studi Pada Pasien Gagal Ginjal Kronik), Yogyakarta, Kanisius, 2015, 169.

Diakses dari https://d.grassets.com/authors/1464673409p5/ 304163.jpg

M.A. Subandi, Reposisi Psikologi Islam ..., 8. Sunu Wibirama, "Bagaimana Membuat Studi Pustaka Yang Baik," Diakses melalui

http://wibirama.com/2013/04/30/su nu-wibirama-bagaimana-membuatstudi-pustaka-yang-baik/ pada tanggal 3 Juli 2015 pukul 20:10 Wib.

Suharsimi Arikunto, Prosedur Penelitian: Suatu Pendekatan Praktik, Jakarta, Rineka Cipta , 2010, hlm. 6

Arabpsynet, "Malik Babikir BadriCurriculum Vitae", diakses melalui http://arabpsynet.com/cvpsychologists/Badri-cv.eng.htm pada tanggal 9 Agustus 2016 jam 11:44 WIB. 
Malik Badri, Tafakkur: Perspektif Psikologi Islam, terjm. Usman Syihab Husnan. Judul asli: Al-Tafakkur min al-Musyahadah ila al-Syuhud: Dirasah al-Nafsiyah al-Islamiyah, Banndung: Rosda Karya, 1996, cover belakang.

Good Reads, "Malik Badri", diakses melalui https://www.goodreads.com/author/ show/304163.Malik_Badri pada tanggal 9 Agustus 2016 jam 13:00 WIB.

Abdul Mujib dan Jusuf Mudzakir, NuansaNuansa Psikologi Islam, Jakarta, Rajawali Pers, 2002, hlm. 22

Malik B. Badri, The Dilemma of Muslim Pshycologists, diterjemahkan oleh Siti Zainab Luxfiati, Dilema Psikolog Muslim, Pustaka Firdaus; Kotak Pos 148 JAT; Jakarta 13001 anggota IKAPI, Jakarta, hlm 2

Iradatul Aini, "Psikologi Islam Mengitegrasikan Ilmu dan Iman," Diakses pada tanggal 28 Februari 2015 pukul 08:17 WIB.

Syed Muhammad Naquib Al-Attas, "Islamic Philosophy: An Introduction," Journal of Islamic Philosophy 1 (2005): 21-22.

Musfir bin Said Az-Zahrani, Konseling Terapi, terjm. Sari Narulita, judul asli: At-taujiih wal irsyaadun nafsi minal Qur'aanil karim wasSunnatin Nabawiyyah (Depok: Gema Insani, 2005), 275-276.

M. Yatimin Abdullah, Studi Akhlak Dalam Perspektif Al-Qur'an (Jakarta: Amzah, 2007), 10.

Ammar Fauzi Heryadi, "Logika Tindakan: Membangun Sistem Nilai Religius," Al-Huda Vol 2 No. 8 (2003): 105.

Robert Frager, Psikologi Sufi: Untuk Transformasi Hati, Jiwa dan Ruh, 78 dan 80.
Ahmad Fuad Pasya, Dimensi Al-Qur'an: Menggali Ilmu Pengetahuan Dari Al-Qur'an, terjm. Muhammad Arifin. Juduk asli: Rahiq Al-'Ilmi wa Al-Ilman, Solo: Tiga Serangkai, 2006, 31.

Iin Tri Rahayu, Islamisasi Psikologi, Jurnal Psikoislamika Vol 1 No 1 Tahun 2004, hlm. 16.

Rosnani Hashim dan Imron Rossidy, "Islamization of Knowledge: A Comparative Analysis of the Conceptions of AI-Attas and AIFaruqi," Intellectual Discourse, Vol 8, No. 1 (2000): 19.

Mahmoud Hamid Al-Migdadi, "Issues in Islamization of Knowledge, Man and Education," Revue Académique des sciences humaines et sociales, $\mathrm{n}^{\circ} 7$ (2011): 6.

Rosnani Hashim dan Imron Rossidy, "Islamization of Knowledge: A Comparative Analysis of the Conceptions of AI-Attas and AIFaruqi,": 21.

Syed Muhammad Naquib Al-Attas, Islam and Secularism (Kuala Lumpur: Art Printing Works Sdn. Bhd., 1993), 44.

Mohammad Muchlis Solichin, "Islamisasi Ilmu Pengetahuan dan Aplikasinya Dalam Pendidikan Islam," Tadris Volume 3. Nomor 1 (2008): 25.

Ikhrom, Titik Singgung Antara Tasawuf, Psikologi Agama dan Kesehatan Mental, Teologia, Volume 19, Nomor 1, Januari 2008, hlm. 1.

Mulyadhi Kertanegara, Integrasi Ilmu: Sebuah Rekonstruksi Holistik (Bandung: Arasy, 2005), 178.

Martyn Shuttleworth, "Islamic Psychology: The History of Psychology," Diakses melalui https://explorable.com/islamic- 
psychology pada tanggal 24 Februari 2015 pukul 15:02 WIB.

Achmad Mubarok, Psikologi Islam: Kearifan dan Kecerdasan Hidup (Jakarta: The IIIT dan Wahana Aksara Prima, 2009), 6. 